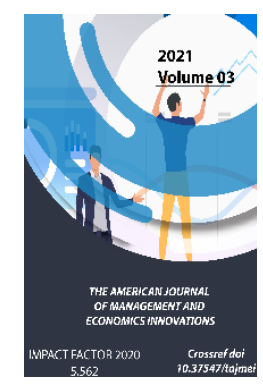

\title{
Improving The Evaluation Of The Effectiveness Of The Supervisory Board In Joint Stock Companies
}

\author{
Navruzov Dilshod Ismatullaevich \\ Mubarak Gas Processing Plant Industrial Safety Group Engineer-Technologist, Listener: \\ Business And Entrepreneurship High School Mba-19 Af-01 2nd Year, Uzbekistan
}

Journal Website: https://theamericanjou rnals.com/index.php/ta jmei

Copyright: Original content from this work may be used under the terms of the creative commons attributes 4.0 licence.

\section{ABSTRACT}

The article discusses the improvement of the Supervisory Board in joint stock companies of Uzbekistan, as well as the improvement of the system for evaluating the effectiveness of the Supervisory Board in joint stock companies. It is recommended to continuously develop the activities of the Supervisory Board as the most important corporate governance body. Recommendations for the introduction of management systems based on the specifics of companies have been developed to improve the activities of the board in joint stock companies.

\section{KEYWORDS}

Generalization of national experience, to improve, increase of the authorized capital, attracting additional investments, supervisory board.

\section{INTRODUCTION}

Decree of the President of the Republic of Uzbekistan dated April 24, 2015 PF-4720 "On measures to introduce modern corporate governance in joint stock companies" and the Cabinet of Ministers of the Republic of Uzbekistan dated October 16, 2006 "On effective management of state-owned enterprises. Resolution No. 215 "On measures to ensure the proper accounting of state property" on the basis of scientific and practical analysis of modern corporate governance practices in joint-stock companies, the introduction of the most advanced achievements, radical reorganization of governing bodies, The organization of diagnostics of the corporate governance 
system on the basis of generalization of national experience, development of manuals and internal corporate documents in order to improve the supervisory board are noted as priorities in our country.

An effective solution to these problems is to improve the organizational and economic mechanism for evaluating the activities of the supervisory board of corporate governance in joint stock companies.

In view of the above, it is important to improve the activities of the supervisory board in the real sector of the country to ensure the sustainable effectiveness of the supervisory board. In order to improve the supervisory board in order to ensure the effective operation of the enterprise, it is necessary to identify specific measures to increase the responsibility of the management of the jointstock company. The following areas are important:

- Increase of the authorized capital;

- Attracting additional investments;

- Improvement of dividend policy in the joint-stock company in order to increase the attractiveness of the company's shares for investors;

- Formation of internal corporate relations between shareholders, members of the supervisory board and executive bodies based on mutual trust and respect;

- Development of a schedule for the evaluation of the Supervisory Board, the elimination of factors affecting it, the evaluation of the Supervisory Board to improve the activities of the Supervisory Board;

- Ensuring gender equality and expanding the rights and opportunities of all women, improving the position of women on the supervisory board.

The main purpose of evaluating the activities of the Board as a collective management body is to determine the level of efficiency of its activities and how the activities meet the development needs of the company. With appropriate preparation and appropriate assessment, this process should encourage information about the role and functions of the supervisory board, job priorities, current procedures, and the combination of knowledge, skills, experience, and personal characteristics that the board should possess.

On the other hand, the supervisory board represents the interests of the shareholders and communicates the position of the company owners to the management. Finally, this body regularly monitors the work of the company's management. The rating systems adopted by most companies take into account the quality of the supervisory board by only one of the above parties. At the same time, an effective supervisory board is able to find an optimal balance between these components: to protect the interests of shareholders and supervisory management without shifting to the level of operational management of management and to form a clear position, for long-term development of the company.

Accordingly, the evaluation of the work of the supervisory board should be carried out in all identified areas.

A table of suggested questions and answers to evaluate the effectiveness of the supervisory board through the following appendices 1,2 is attached.

The development of the Supervisory Board not 
only enhances the reputation of the company, but also eliminates conflicts between its shareholders, managers and team members, the creation of a healthy environment becomes a key factor in their development.

Therefore, questionnaires were developed to assess the performance of its members, which were divided into two parts. In the first part, you should evaluate the effectiveness of each member of the supervisory board based on their actions during the meetings. In the second part of the questionnaire, you should evaluate the experience, skills and professional qualities of the board member.

\begin{tabular}{|c|c|}
\hline Indicators & $\begin{array}{l}\text { Members of the Supervisory Board of the } \\
\text { joint-stock company Last name, Name }\end{array}$ \\
\hline $\begin{array}{l}\text { Expresses well-thought-out and open views on the } \\
\text { issues discussed at the Board meetings. }\end{array}$ & \\
\hline $\begin{array}{l}\text { He comes to Council meetings well prepared, which } \\
\text { allows him to express his views on the issues on the } \\
\text { agenda and make a valuable contribution to decision- } \\
\text { making. }\end{array}$ & \\
\hline $\begin{array}{l}\text { If he is convinced he is right, he is ready to defend his } \\
\text { position to the end. }\end{array}$ & \\
\hline $\begin{array}{l}\text { Asks for more information and does not vote if he or } \\
\text { she does not understand the issue to be voted on. }\end{array}$ & \\
\hline $\begin{array}{l}\text { He has valuable experience and knowledge and } \\
\text { makes a great contribution to the performance of the } \\
\text { functions assigned to the Council. }\end{array}$ & \\
\hline $\begin{array}{l}\text { His behavior contributes to the creation of a critical } \\
\text { environment and encourages the organization of an } \\
\text { effective discussion. }\end{array}$ & \\
\hline Quickly delves into the essence of the problem. & \\
\hline $\begin{array}{l}\text { He behaves firmly, actively, and knows how to get } \\
\text { the matter to the end. }\end{array}$ & \\
\hline $\begin{array}{l}\text { He is well aware of the issues that need to be } \\
\text { considered and resolved. }\end{array}$ & \\
\hline
\end{tabular}

Application 1.

Please evaluate the performance of each member of the company's supervisory board, putting the appropriate rating in the appropriate column. After each approval, how consistent the meeting issues are, including board members, will be resolved. It is important to evaluate the supervisory board. For example, a board member always behaves like this at board meetings - "5", often - "4", rarely - "3", if you have not seen a board member behave in such a way at meetings - "2" 


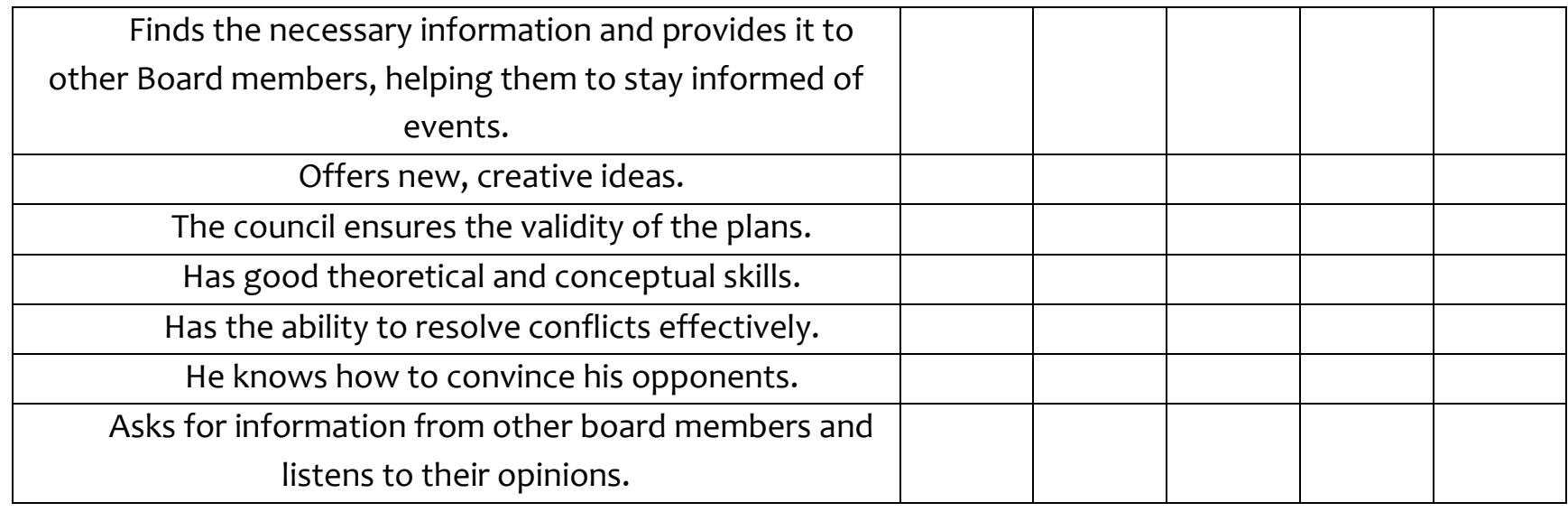

\section{Application 2.}

Please, in , evaluate the experience, skills and professional qualities of each member of the Supervisory Board of JSC " " and mark the appropriate column.

$2=$ needs improvement

3 = satisfactory

4 = good

$5=$ excellent

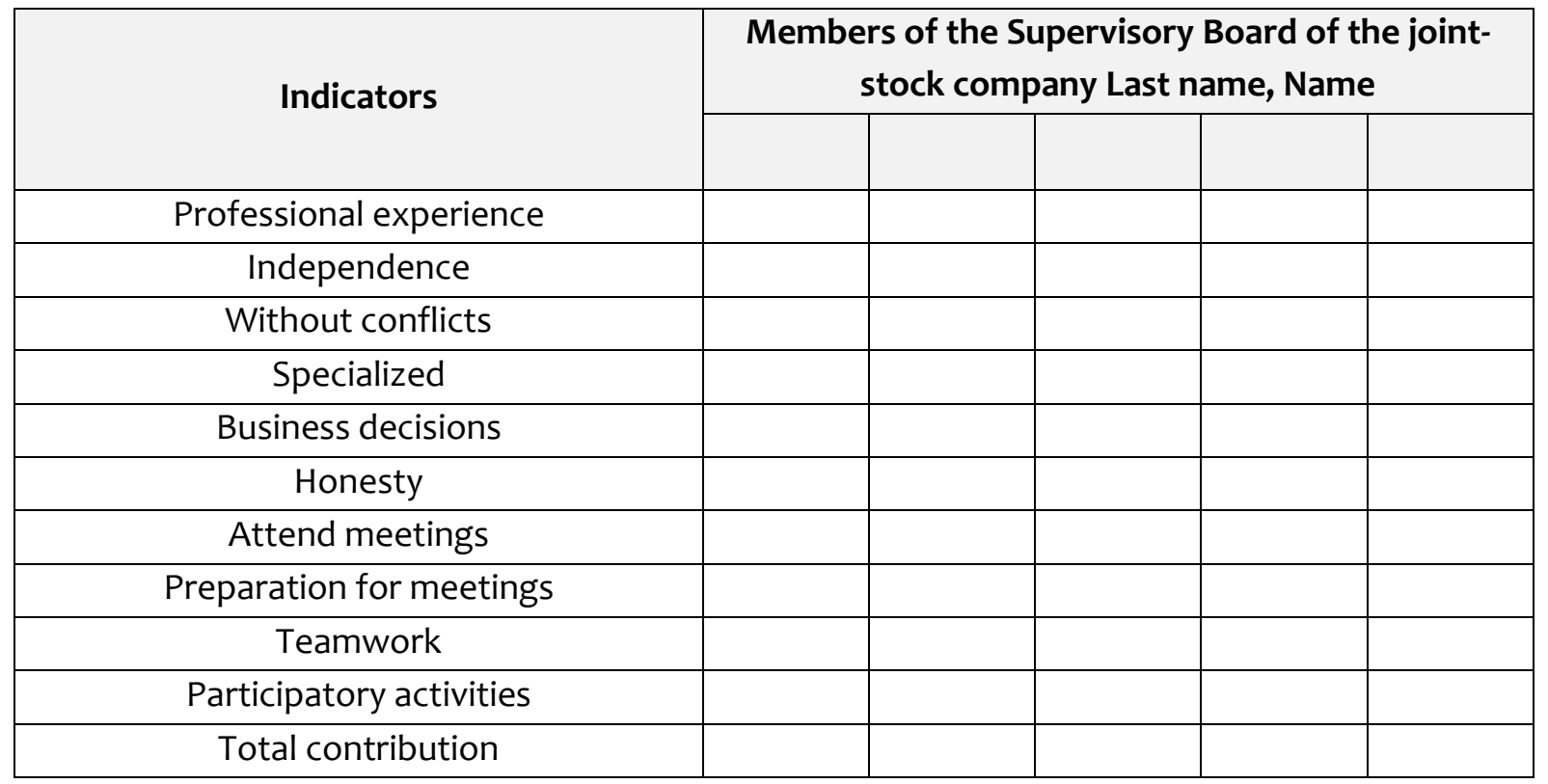




\section{CONCLUSION}

The evaluation process examines what the board has achieved and how it has achieved it. The Board is responsible for evaluating areas of governance. Employees or independent consultants are usually responsible for evaluating programs and services. The functions of the evaluation board should include: the board (meetings, individual board members, committees, etc.); development of consultations (recruitment and referral process, management structure); council goals, mission and strategic plan; senior staff (i.e. executive management).

No matter what type of evaluation process is used, it must be transparent, otherwise this evaluation process has the potential to negatively affect the production and staff of that organization.

\section{REFERENCES}

1. Suyunov D.X., Khoshimov E.A., Khusainov Sh.A. Corporate governance: problems and modern solutions. Tashkent city: 2021.

2. Rixsiev D.X. Sovershenstvovanie sistemy otsenki effektivnoy deyatelnosti nablyudatelnogo soveta $\mathrm{v}$ Uzbekistane // Mezhdunarodnaya nauchnoprakticheskaya online konferentsiya «Puti effektivenogo primeneniya zarubejnoy praktiki v formirovanii tsifrovoy ekonomiki». - Tashkent: TFI, May 20, 2020. p. 271 - 275.

3. Mark Fenwick, Erik P.M. "Evaluating the Board of Directors: International Practice," Law Working Paper № 425/2018.

4. Merganov A. M. Voprosy povbsheniya effektivnosti estestvennyx monopoliy // Jurnal nauchnyx publikatsiy aspirantov i doktorantov. - 2016. - №. 3. - S. 18-19. 